\title{
Reduction of $\mathrm{O}_{2}$ to Superoxide Anion $\left(\mathrm{O}_{2}{ }^{-}\right)$in Water by
}

\section{Heteropolytungstate Cluster-Anions}

\author{
Yurii V. Geletii, ${ }^{\dagger}$ Craig L. Hill, ${ }^{\dagger}$ Rajai H. Atalla, ${ }^{\ddagger}$ and Ira A. Weinstock ${ }^{\S *}$
}

'Department of Chemistry, Emory University, Atlanta GA 30322, USA. "Chemistry and Pulping

Research Work Unit, USDA Forest Products Laboratory, Madison WI 50726, USA. ${ }^{\circledR}$ Department of

Chemistry, City College of The City University of New York, New York, NY, 10031, USA.

*Author to whom correspondence should be addressed. E-mail: iaw@sci.ccny.cuny.edu

Information included:

I. Reactions of $\mathbf{1}_{\text {red }}, \mathbf{2}_{\text {red }}$, and $3_{\text {red }}$ with $\mathrm{O}_{2}$ in the presence of $\mathrm{H}_{2} \mathrm{O}_{2}$.

II. Effect of ionic strength on the rate of reaction of $\mathbf{1}_{\text {red }}$ with $\mathbf{O}_{2}$.

III. Effect of $\mathrm{AlW}_{12} \mathrm{O}_{40}{ }^{5-}\left(1_{0 x}\right)$ on the rate of reaction of $1_{\text {red }}$ with $\mathrm{O}_{2}$.

IV. Calculation of the rate constant, $k_{7}$ for the reaction in eq 7 of the text.

\section{Reactions of $\mathbf{1}_{\text {red }}, \mathbf{2}_{\text {red }}$, and $\mathbf{3}_{\text {red }}$ with $\mathrm{O}_{2}$ in the presence of $\mathrm{H}_{2} \mathrm{O}_{2}$.}

Direct reactions of $\mathbf{1}_{\text {red }}$ with $\mathrm{H}_{2} \mathrm{O}_{2}$, in the absence of $\mathrm{O}_{2}$, showed the reaction to be slow. However, the system did not obey simple kinetics. Moreover, the $\mathrm{O}_{2}$-free reaction between $\mathbf{1}_{\text {red }}$ and $\mathrm{H}_{2} \mathrm{O}_{2}$ doesn't accurately model the system of interest, which initially contains $\mathrm{O}_{2}$, and after reaction begins, contains both $\mathrm{O}_{2}$ and $\mathrm{H}_{2} \mathrm{O}_{2}$, along with small steady-state concentrations of superoxide $\left(\mathrm{HO}_{2}{ }^{-}\right.$and $\left.\mathrm{O}_{2}{ }^{-}\right)$. Complex reaction pathways may be operable in this 'actual' system that are not accessible in the (initially) $\mathrm{O}_{2}$ free reactions between the reduced Keggin anions and $\mathrm{H}_{2} \mathrm{O}_{2}$. Thus, the following method was used to model conditions present in actual reactions with $\mathrm{O}_{2}$. 
Solutions of $\mathbf{1}_{\text {red }}$ were mixed in a stopped-flow apparatus with solutions uniformly saturated with $\mathrm{O}_{2}$, but that also contained a wide range of $\mathrm{H}_{2} \mathrm{O}_{2}$ concentrations. Initial rates of consumption of $\mathbf{1}_{\text {red }}$ (quantified by UV-vis), were plotted versus $\left[\mathrm{H}_{2} \mathrm{O}_{2}\right]$. In these plot, increases in the rate of consumption of $\mathbf{1}_{\text {red }}$ with increase in $\left[\mathrm{H}_{2} \mathrm{O}_{2}\right]$ reflects 'background' contributions (reaction of $\mathbf{1}_{\text {red }}$ with $\mathrm{H}_{2} \mathrm{O}_{2}$ ), to rates of reaction of $\mathbf{1}_{\text {red }}$ with $\mathrm{O}_{2}$. At pH $=2.1$ in $50 \mathrm{mM}$ sulfate buffer, rates increase only slightly when $\left[\mathrm{H}_{2} \mathrm{O}_{2}\right]$ is in the range 0 to $1.5 \mathrm{mM}$ (Figure S1). To reliably determine initial rates for electron transfer to $\mathrm{O}_{2}$, contributions from electron transfer to $\mathrm{H}_{2} \mathrm{O}_{2}$ must be small in the early stages of the reaction (ca. $10 \%$ conversion). For initial $\mathbf{1}_{\text {red }}$ concentrations of $0.8 \mathrm{mM}$ (the largest concentration used in kinetic studies with $\mathrm{O}_{2}$ ), $10 \%$ conversion, according to eq 1 , gives $0.04 \mathrm{mM} \mathrm{H}_{2} \mathrm{O}_{2}$. The vertical line in Figure $\mathrm{S} 1$ (drawn at $\left[\mathrm{H}_{2} \mathrm{O}_{2}=0.04 \mathrm{mM}\right]$ ) shows that, for reactions of $\mathbf{1}_{\text {red }}$ or $\boldsymbol{2}_{\text {red }}$ with $\mathrm{O}_{2}$, oxidation of the reduced $\alpha$ Keggin ions by $\mathrm{H}_{2} \mathrm{O}_{2}$ makes a negligible $(<1-2 \%)$ contribution to observed rates of electron transfer to $\mathrm{O}_{2}$. For analogous reactions of $\mathbf{3}_{\text {red }}$ at $\mathrm{pH} 1.3(50 \mathrm{mM} \mathrm{HCl})$, the increase in initial rate values is slightly larger, but still relatively small (it reaches a maximum values of $<15 \%$ at the vertical line in Figure S1). Most importantly, however, contributions are considerably smaller than this $(<3-5 \%)$ earlier in the reaction with $\mathrm{O}_{2}$, at which $\mathrm{H}_{2} \mathrm{O}_{2}$ concentrations are much less than $0.04 \mathrm{mM}$.

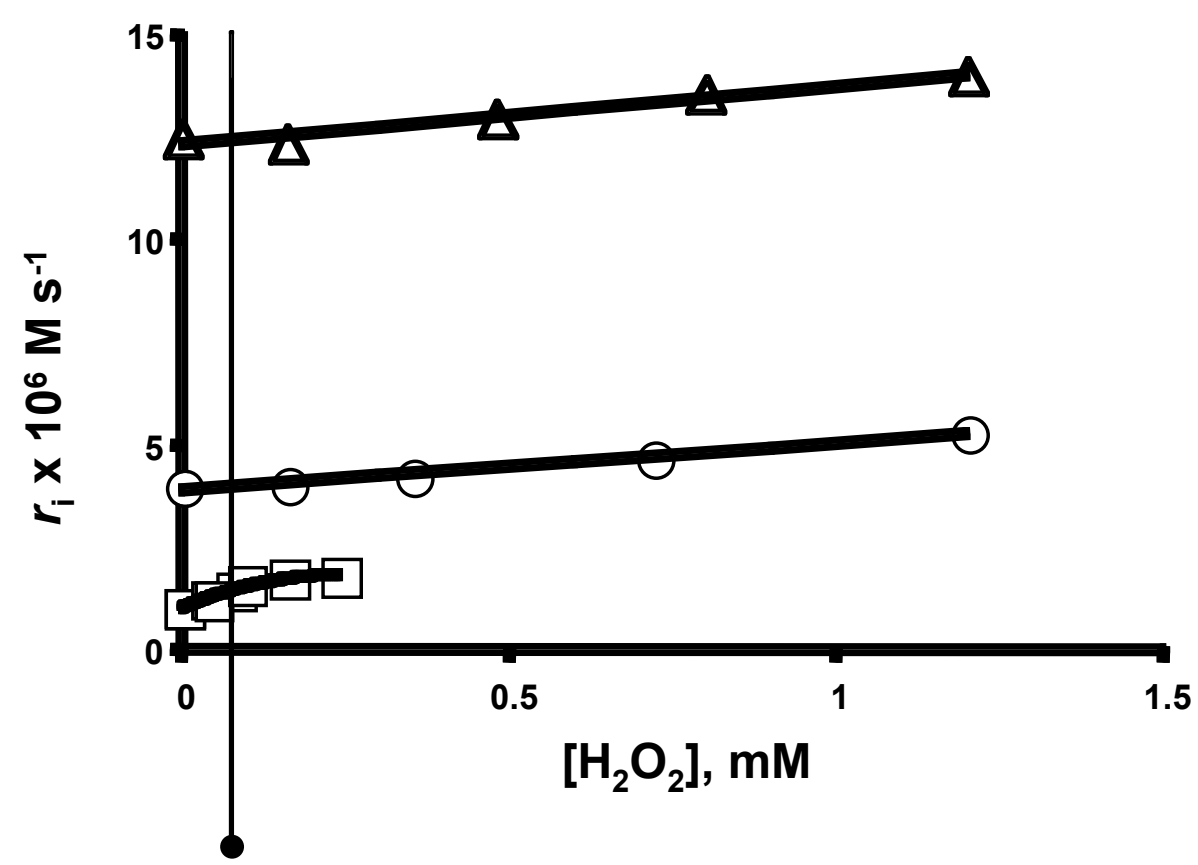

$10 \%$ conversion, at which $\left[\mathrm{H}_{2} \mathrm{O}_{2}\right]=0.04 \mathrm{mM}$ 
Figure S1. Initial rates of consumption of $\alpha-\mathrm{AlW}_{12} \mathrm{O}_{40}{ }^{6-}, \mathbf{1}_{\text {red }}(\Delta), \alpha-\mathrm{SiW}_{12} \mathrm{O}_{40}{ }^{5-}, \boldsymbol{2}_{\text {red }}$ (o), and $\mathrm{PW}_{12} \mathrm{O}_{40}{ }^{4-}, \mathbf{3}_{\text {red }}()$, at constant initial $\left[\mathrm{O}_{2}\right](0.58 \mathrm{mM})$, upon increase in $\left[\mathrm{H}_{2} \mathrm{O}_{2}\right](50 \mathrm{mM} \mathrm{NaCl}, 25$ $\left.{ }^{\circ} \mathrm{C}\right)$. Other conditions: $\left[\mathbf{1}_{\text {red }}\right]$ and $\left[\mathbf{2}_{\text {red }}\right]$ were both $0.5 \mathrm{mM}$, in $50 \mathrm{mM}$ sulfate buffer at pH $2.1 ;\left[\mathbf{3}_{\text {red }}\right]$ was $0.65 \mathrm{mM}$, in $50 \mathrm{mM} \mathrm{HCl}(\mathrm{pH} 1.3)$.

\section{Effect of ionic strength on the rate of reaction of $\mathbf{1}_{\text {red }}$ with $\mathrm{O}_{2}$.}

Initial rates were determined over a range of $[\mathrm{NaCl}]$ values $(0.01$ to $0.81 \mathrm{M})$, at neutral $\mathrm{pH}$. $\mathrm{NaCl}(\mathrm{s})$ was dissolved in water, and the salt solution was then saturated with $\mathrm{O}_{2}$ at $25{ }^{\circ} \mathrm{C}$. Each $\mathrm{O}_{2}$-saturated $\mathrm{NaCl}$ solution was then mixed in a stopped flow instrument, at a 1:1 v:v ratio, with a solution of $\mathbf{1}_{\text {red }}(1.5$ $\mathrm{mM}$ ) in $100 \mathrm{mM}$ phosphate buffer ( $\mathrm{pH} 7.2$ ), and initial rates of decrease in the absorbance of $\mathbf{1}_{\text {red }}$ were quantified by UV-vis at $700 \mathrm{~nm}$. The results are provided in Table S1.

Table S1. Initial Rates $\left(r_{\mathrm{i}}\right)$ and Estimated Rate Constants, $k$, for Reaction of $\mathbf{1}_{\text {red }}$ with $\mathrm{O}_{2}$ at Several $[\mathrm{NaCl}]$ Values

\begin{tabular}{|l|l|l|l|l|}
\hline$[\mathrm{NaCl}], \mathrm{mM}$ & 10 & 200 & 500 & 810 \\
\hline$r_{\mathrm{i}} \times 10^{5}, \mathrm{M}^{-1} \mathrm{~s}^{-1}$ & $2.1 \pm 0.15$ & $2.15 \pm 0.15$ & $1.95 \pm 0.15$ & $1.6 \pm 0.15$ \\
\hline$\left[\mathrm{O}_{2}\right]^{\mathrm{a}}, \mathrm{mM}$ & 0.615 & 0.57 & 0.52 & 0.46 \\
\hline$k,{ }^{\mathrm{b}} \mathrm{M}^{-1} \mathrm{~s}^{-1}$ & $46 \pm 4$ & $50 \pm 4$ & $50 \pm 4$ & $46 \pm 4$ \\
\hline
\end{tabular}

Conditions: $\left[\mathbf{1}_{\text {red }}\right]_{\mathrm{o}}=0.75 \mathrm{mM}, 50 \mathrm{mM}$ phosphate buffer, $\mathrm{pH} 7.2,25^{\circ} \mathrm{C}$. ${ }^{\mathrm{a}}$ After $1: 1 \mathrm{mixing}$, calculated by interpolation of data from Table 4500-0:1, ${ }^{1}$ the concentration of $\mathrm{O}_{2}$ in pure water at $25^{\circ} \mathrm{C}$ and $1 \mathrm{~atm}$ total pressure (760 torr; $\mathrm{O}_{2}$ pressure + water vapor pressure) is $1.24 \mathrm{mM} ;{ }^{2 \mathrm{~b}} k=\mathrm{r}_{\mathrm{i}} /\left(\left[\mathbf{1}_{\mathrm{red}}\right]_{\mathrm{o}}\left[\mathrm{O}_{2}\right]_{\mathrm{o}}\right.$.

\section{Effect of $\mathrm{AlW}_{12} \mathrm{O}_{40}{ }^{5-}\left(1_{\mathrm{ox}}\right)$ on the rate of reaction of $1_{\text {red }}$ with $\mathrm{O}_{2}$.}

Initial rates were determined at 3 concentrations of $\mathbf{1}_{\mathrm{ox}}(0,5.0$ and $10 \mathrm{mM})$. A solution of $\mathbf{1}_{\mathrm{ox}}$ in 50 $\mathrm{mM}$ phosphate buffer ( $\mathrm{pH} 7.2$ ), $100 \mathrm{mM} \mathrm{NaCl}$, and saturated with $\mathrm{O}_{2}$ at $25{ }^{\circ} \mathrm{C}$, was mixed in a stopped flow instrument, at 1:1 ratio, with a de-aerated solution of $\mathbf{1}_{\text {red }}$ (ca. $1.0 \mathrm{mM}$ ) in $50 \mathrm{mM}$ phosphate buffer (pH 7.2) and $100 \mathrm{mM} \mathrm{NaCl}$. Initial rates $r_{\mathrm{i}}$, were identical at all $3 \mathbf{1}_{\text {ox }}$ concentrations: $r_{\mathrm{i}}=1.4 \pm 0.1 \times 10^{-}$ ${ }^{5} \mathrm{M}^{-1} \mathrm{~S}^{-1}$ 


\section{Calculation of the rate constant, $\boldsymbol{k}_{7}$ for the reaction in eq 7 of the text.}

Rate constants for electron transfer from $\mathbf{1}_{\text {red }}$ to $\mathrm{HO}_{2}{ }^{*}$ were estimated using the Marcus cross relation, with the following two assumptions: 1) the reaction occurs via an outer-sphere mechanism, and 2) reaction of $\mathbf{1}_{\text {red }}$ with $\mathrm{HO}_{2}{ }^{-}$is fast relative to reaction between $\mathbf{1}_{\text {red }}$ (a 6- ion) and $\mathrm{O}_{2}{ }^{-}$. In defense of the first assumption, outer-sphere reactions are typically slower than inner-sphere pathways, such that the results obtained by application of the Marcus cross relation will, if anything, underestimate the rate constant, $k_{7 \mathrm{a}}$ for reduction of $\mathrm{HO}_{2}{ }^{\circ}$ by $\mathbf{1}_{\text {red }}$. Thus, assumption of an outer-sphere mechanism provides a conservative (more demanding) test for comparing rates of reaction between $\mathrm{HO}_{2}{ }^{\circ}$ and $\mathbf{1}_{\text {red }}$ to rates of superoxide disproportionation. The Marcus cross relation was applied using: 1) the experimentally determined value for $k_{11}$, the zero ionic-strength rate constant for self-exchange between $\mathbf{1}_{\text {red }}$ and $\mathbf{1}_{\text {ox }},{ }^{3}, 2$ ) the experimentally determined value for the rate of electron self-exchange between $\mathrm{HO}_{2}{ }^{\circ}$ and $\mathrm{HO}_{2}^{-}, 4$ and 3) the $\mathrm{pH}$-independent value ( $\mathrm{pH} \mathrm{14)}$ for the reduction potential of the protonated superoxide/hydrogen peroxide anion $\left(\mathrm{HO}_{2}{ }^{\circ} / \mathrm{HO}_{2}^{-}\right)$couple. (Use of the $\mathrm{pH}$-independent value may lead to underestimation of the rates of electron transfer from $\mathbf{1}_{\text {red }}$ to $\mathrm{HO}_{2}{ }^{\circ}$ at low $\mathrm{pH}$ values, again providing a conservative, and more demanding, comparison between electron transfer-from $\mathbf{1}_{\text {red }}$ to $\mathrm{HO}_{2}{ }^{\circ}$-and disproportionation.) The same assumptions and method was used to estimate rate constants for electron transfer from $\boldsymbol{2}_{\text {red }}$ and $\mathbf{3}_{\text {red }}$ to $\mathrm{HO}_{2}^{*}$.

Additional details are as follows: The rate constant for electron transfer from $\mathbf{1}_{\text {red }}$ to $\mathrm{HO}_{2}{ }^{*}$ was calculated using the Marcus cross relation. For this, the $\mathrm{pH}$-independent $E_{1 / 2}$ value of $+0.81 \mathrm{~V}$ was used for the potential of the $\mathrm{HO}_{2}{ }^{\circ} / \mathrm{HO}_{2}^{-}$couple, and $2 \AA$ was used for the radius of $\mathrm{HO}_{2}{ }^{\circ}$ (the results were effectively the same when radii of 1.33 and $3 \AA$ were used). In addition, a value of $k_{22}=0.17 \mathrm{M}^{-1} \mathrm{~s}^{-1}$ was used for the effective rate constant for electron self exchange between $\mathrm{HO}_{2}{ }^{\circ}$ and $\mathrm{HO}_{2}^{-}$. The reported (directly measured) value of $k_{22}$ is $17 \mathrm{M}^{-1} \mathrm{~s}^{-1}$. However, this was decreased by 2 orders of magnitude to account for the difference in size between the Keggin anions and $\mathrm{HO}_{2}{ }^{\cdot 5-7}$ This, again, is a conservative step in that it decreases the estimated $r_{7} / r_{8}$ ratios by two orders of magnitude. 
Results: The rate constant for electron transfer from $\mathbf{1}_{\text {red }}$ to $\mathrm{HO}_{2}{ }^{\circ}\left(k_{7}\right)$ calculated as described above, (associated with eq 7 in the text) $=10^{8} \mathrm{M}^{-1} \mathrm{~s}^{-1}$. The analogous rate constants for $\mathbf{3}_{\text {red }}$ is $k_{\mathrm{ET}}=5 \times 10^{7} \mathrm{M}^{-1} \mathrm{~s}^{-}$

1. For $2_{\text {red }}, k_{\mathrm{ET}}=2 \times 10^{8} \mathrm{M}^{-1} \mathrm{~s}^{-1}$. These values are very close to one another. This is due, in part, to variation in the reorganization energies associated with the self-exchange rate constants, $k_{11}$, of the three Keggin anion couples. It also reflects the corrected free energies include "work" terms associated with formation of the successor complexes. These work terms increase in energy (and cause a decrease in rate), as $\mathrm{X}^{\mathrm{n+}}$ is varied from $\mathrm{P}^{5+}$ to $\mathrm{Si}^{4+}$ to $\mathrm{Al}^{3+}$ (and anion charges decrease accordingly). This attenuates the increase in rate that would otherwise accompany the more favorable free energies for electron donation from the more negatively charged Keggin anions. This phenomenon is analogous to the one described in more detail in the Discussion section for electron transfer to $\mathrm{O}_{2}$.

\section{References}

1. Eaton, A. D.; Franson, M. A. H.; Greenberg, A. E.; Clesceri, L. S., Standard Methods for Examination of Water and Wastewater. 18th ed.; American Public Health Association: New York, 1992; p 1200.

2. Clever, H. L.; Young, C. L.; Battino, R.; Derrick, M. E.; Katovic, V.; Pogrebnaya, V. L.; Usov, A. P.; Baranov, A. V., Solubility data. Oxygen-electrolyte-water system. Solubility Data Series 1981, 7 , 56-189.

3. Geletii, Y. V.; Hill, C. L.; Bailey, A. J.; Hardcastle, K. I.; Atalla, R. H.; Weinstock, I. A. Inorg. Chem. 2005, 44, 8955-8966.

4. $\quad$ Lind, J.; Shen, X.; Merényi, G.; Jonsson, B. Ö. J. Am. Chem. Soc. 1989, 111, (19), 7654-7655.

5. Merényi, G.; Lind, J.; Jonsson, M. J. Am. Chem. Soc. 1993, 115, (11), 4945-4946.

6. Zahir, K.; Espenson, J. H.; Bakac, A. J. Am. Chem. Soc. 1988, 110, 5059-5063.

7. Weinstock, I. A. Chem. Rev. 1998, 98, (1), 113-170. 